Originalveröffentlichung in: Deborah A. Green, Laura S. Lieber (Hg.), Scriptural Exegesis. The Shapes of

Culture and the Religious Imagination. Essays in Honor of Michael Fishbane, Oxford 2009, S.13-24

\title{
1 \\ Myth as historia divina and historia sacra
}

\author{
Jan Assmann
}

In his book Biblical Myth and Rabbinic Mythmaking, ${ }^{1}$ Michael Fishbane vehemently and convincingly rejects the widespread idea that, in the words of Yehezkel Kaufmann, 'biblical religion is in essence non-mythological',2 and that the turn from polytheism to monotheism meant a categorical rejection of myth. ${ }^{3}$ According to Fishbane, myth in its various intellectual and literary forms constitutes rather a continuity between prebiblical polytheism, biblical religion, and postbiblical rabbinic Judaism. Fishbane's definition of myth as referring to '[sacred and authoritative] accounts of the deeds and personalities of the gods and heroes during the formative events of primordial times, or during the subsequent historical interventions or actions of these figures which are constitutive for the founding of a given culture and its rituals's accommodates not only Babylonian, Egyptian, and Greek tales about gods but also biblical accounts of God's interventions into history, such as, above all, the story of Exodus.

While deconstructing the conventional opposition of myth and monotheism, however, Fishbane introduces another distinction that allows the demarcation of a shift within this continuity, at least between biblical and misdrashic ways of speaking about God: 'Moreover, the intensified focus on the pathos of God, and His participation in the events of biblical Israel, marks a shift from the historia sacra of the people (the keynote of Scripture) to the historia divina of myth (a keynote of Midrash). ${ }^{5}$ Historia divina refers to the general concept of myth applying to extrabiblical, biblical, and postbiblical religions as the history of gods or God, whereas historia sacra refers to the specifically monotheistic and biblical, both Jewish and Christian, concept of myth as history being preordained and governed by God.

I consider Fishbane's distinction a major breakthrough in our understanding not only of biblical and postbiblical history but also of ancient oriental thought in general. As an Egyptologist, I am primarily interested not so much in the shift from biblical to postbiblical Judaism or Christianity as in the shift from prebiblical to biblical myth, and feel invited to tentatively apply Fishbane's distinction to ancient Egyptian and ancient Mesopotamian mythology. 
Fishbane is certainly right (as was Thomas Mann in his Joseph novels ${ }^{6}$ ) to reject the easy construction of this shift in terms of 'myth versus monotheism', since myth is on both sides. Yet a shift there is, and his distinction between historia divina and historia sacra may perhaps provide a conceptual tool for a more convincing description of this difference. Is it possible to describe the contrast between the polytheistic and the biblical ways of dealing with history as a shift from historia divina to historia sacra? Is the term historia sacra applicable at all to extrabiblical phenomena?

Let us start from an attempt to define these terms. Historia divina is the history of God or gods. This concept presupposes that God 'has' a history-as opposed to the conception of a categorically transcendent and timeless God, a concept which is certainly anachronistic with respect to the Bible but central to later Christian and Islamic theology. Historia sacra is history as shared by God or gods in one way or other. 'Having' a history is, of course, no problem with regard to Egyptian, Babylonian, or Greek gods. Historia divina is the proper form of speaking about gods existing in a divine world or pantheon. Historia divina is the narrative structure of the divine world. Its logical counterpart is not historia sacra but historia humana, to be defined as the narrative structure of the human world. For the monotheistic concept of God, there is no divine world to share. ${ }^{7}$ The only possibility for God to 'have' a history is to share the human realm of history, which by divine participation is then turned into historia sacra.

In what follows I will shift the emphasis from theology to history. By history, be it historia divina, historia sacra, or historia profana or humana, I understand not the past as such, but the narrative representation of the past. My thesis is that such a thing as the narrative representation of the past is anything but normal and self-evident. It requires a general cultural option for change over against identity and continuity. The past, in order to become the subject of such a representation, must in itself possess a kind of narrative structure. There must be something to tell in order to provoke a representation of any importance and interest. The concept of narration implies change and transformation; this additional definition is important. The typical structure of an event is the transformation of a situation A into its contrary $\bar{A}$. It is this event-structure that makes the past narratable. If we apply this concept of narrative structure to historia divina, we meet with a plethora of myths that tell of such events transforming a state $A$ into a state $\bar{A}$. The gods have worked all the changes that constitute present reality.

The past, however, in which these actions took place is of a very specific kind. It is an 'absolute past' that keeps equal distance to a moving present. Mircea Eliade characterized this concept of a mythical past by the Latin formula 'in illo tempore'. ${ }^{8}$ Mythical time belongs to another temporality 
than that to which historical time belongs. Events in historical time share the same temporality with the present, which means that the distance between the historical event and a given moment in present time can be measured in terms of years and months. Mythical time, on the other hand, does not allow for this form of localization and distanciation. It constitutes a temporality of its own. Its 'pastness' is of a kind that may be re-presented or 'presentified' by ritual or dramatic or rhapsodic performance.

Historia divina is about events in the absolute past, 'in illo tempore', and history is about events in the historical past with a precise place in chronology. History as the narrative representation of the past reflects the narrative structure of the human world (in terms of events and transformations), in the same way as the narrative representation of the absolute past or myth reflects the narrative structure of the divine world.

Equipped with these definitions and conceptual tools, we can see that, in fact, there is comparatively little in terms of historia divina (in the strict sense of a narrative presentation of a divine past 'in illo tempore') in the Bible, but an enormous number of datable events and a extraordinarily comprehensive representation of the past from the first day of Creation down to the reign of the Persian king Artaxerxes. In ancient Egypt, on the other hand, there is a plethora of historia divina, that is, narrative representations of events taking place in the divine world, and a very conspicuous absence of any narrative representation of the historical or human past. Instead of history, defined as the narrative representation of the past, we meet with anti-history, which may be defined as the non-narrative representation of the past. ${ }^{9}$ Examples of non-narrative representations of the past may be found in annals and king-lists, that is, in enumerations of facts but not of events in the sense of transformatory processes that lead to something new instigating narration and remembering. Non-narrrative representations of the past are tools of chronological orientation. Narrative representations of the past are forms of collective memory and identity; they are 'the intellectual form in which a society gives account to itself of its past', to quote Johan Huizinga's famous definition of history. ${ }^{10}$ They are related to memory and identity, because they tell of events that brought about, and are therefore able to explain, the present as the result of a development.

What we learn from these observations is that the past is not, as such, already an object of narrative representation. There is no natural drive to represent the past in the form of historical narrative. Representing the past or 'history' requires generators of meaning in order to make the past narratable, to turn facts into events, and to relate past events to present situations. The early states, such as ancient Egypt and Mesopotamia, had a strong need for chronological orientation but obviously not for history. This state of affairs applies above all to ancient Egypt, and is beautifully reflected in an anecdote 
told by Herodotus. When Hecataeus of Miletos came to Thebes in Egypt, he boasted of his pedigree ending with a god in the sixteenth generation. The Egyptian priests took the noble Hecataeus into their temple and showed him 341 statues of highpriests - 341 generations of priests, one being the son and successor of the other, without any deity interfering. 'This means then,' Herodotus resumes, 'that for a time-period of 11,340 years, exclusively human kings ruled over Egypt', making sure that we are dealing here with an exclusively human history, or rather, past, because these 11,340 years lack the narrative structure they would need to become history. This is made clear by Herodotus' additional remarks: 'Within this time-span, the sun is reported to have changed its course several times. Twice it has risen where it now sets and has set where it now rises. But this did not cause any changes in the Egyptian world, neither in the vegetation nor in the activity of the river, nor with regard to diseases and death in the human world' (2.143). This seemingly absurd remark nonetheless offers a deep insight into the non-narrative structure of the Egyptian concept of the past. Narrative is about time as change. Time without change can only be counted or measured, not narrated. The ancient Egyptian king-list is a tool of time-reckoning and chronological orientation, but not a narrative representation of the past. ${ }^{11}$ The absence of narrative representation may be called anti-history, since it is the result of a cultural option against history.

The distinction between history and anti-history goes back to Claude LéviStrauss and his distinction between cold and hot societies. Cold societies, according to Lévi-Strauss, 'strive, by means of the institutions they are giving themselves, to erase quasi-automatically the effect which historical factors could have on their equilibrium and their continuity' ('gràce aux institutions qu'elles se donnent, à.... annuler de façon quasi automatique l'effet que les facteurs historiques pourraient avoir sur leur équilibre et leur continuité'). 'Hot societies', on the other hand, 'are characterized by a desire for change and interiorize their history (leur devenir historique) in order to make it the motor of their development.'12 Lévi-Strauss is interested in deconstructing the conventional concept of oral societies as lacking history. Coldness, in his view, is not a lack but a positive achievement. He is right, and the decisive term is 'institution'.

I must admit that I do not believe in hot and cold societies, but I believe in institutions producing cultural 'heat' or 'coldness', that is, freezing or emphasizing, excluding or featuring change. The Egyptian king-list is an institution that freezes change, a fact perspicaciously recognized by Herodotus. For the Egyptian understanding, change belongs to the time of the gods, when the world was created and the institutions were founded. These are the changes that are narrated by the myths. If changes occur in the human time of history, they are interpreted as irruptions of chaos, which may only be lamented but 
not narrated, because they lack meaning and coherence. The Egyptian word for 'event', kheperut, has strong negative connotations, as in China, where people wish each other well by wishing for 'eventless times'. Kheperut is something to be avoided and fenced off. In a wisdom text, we read that God gave humans magic as a weapon to ward off the blow of kheperut. ${ }^{13}$

In Mesopotamia the situation is slightly different. The Sumerian state also created a king-list as a tool of time-reckoning, which is very similar to the Egyptian king-list. ${ }^{14}$ Both show a tripartite structure, starting with the creation of the world and a succession of gods, and then giving a list of heroes or demigods until they pass to human kings, of whom they give a complete list down to the reigning king. ${ }^{15}$ There is, however, a striking difference between the Egyptian and the Mesopotamian king-lists, in that the Mesopotamian list shows some remarkable beginnings of narrative elaboration. Moreover, there are not a few texts outside the king-list tradition that stretch back over a series of different reigns into the remote past. ${ }^{16}$ An early text of this genre, known under the title 'Curse on Aggade',17 is the history of the rise and fall of the Sargonid Dynasty in the twenty-third and twenty-second centuries BCE. Among other events, it relates how King Naramsin destroyed the temple of Enlil in Nippur, and how Enlil answered this crime by sending the Guteans, who put an end to the ruling dynasty. The Neo-Babylonian 'Weidner Chronicle' (first century BCE) reaches much farther back in time. This chronicle gives an account of a series of dynasties, and connects the success of a king's reign with his attitude towards the Esagila, the temple of Marduk in Babylon. ${ }^{18}$ In various cases, the fall of a dynasty and the transition of rule from one dynasty to another are explained by a guilt that one or several rulers accumulated during their reign. The fall of the empire of $U r$ is traced back to certain forfeits committed by King Shulgi. ${ }^{19}$ The juridical concept of guilt and punishments gives meaning to history and coherence to the chain of events and the sequence of dynasties. Here, as in Egypt, the concept of 'event' is invested with rather negative connotations. But the difference between the Egyptian and the Mesopotamian concepts of event is obvious. In Egypt, the event is a manifestation of chaos and contingency, without any meaning. In Mesopotamia, however, the event is full of meaning. It is read as the manifestation of the punishing will of a divinity whose anger has been raised by the king. ${ }^{20}$

What are, in Mesopotamia, the generators of history, the factors that bestow meaning and coherence onto past facts and turn them into narratable events? Two ideas seem to me decisive for the Mesopotamian concept of history: one is the idea of 'connective justice', the connection of guilt and punishment that connects events in terms of cause and consequence; ${ }^{21}$ and the other is the role of the gods, who intervene in human history as agents of punishment. We see that we are not dealing here with purely human history, but with a kind of history in 
which the gods are heavily involved, and that it is this divine involvement that turns facts into events and makes the past narratable. In other words, history emerges in Mesopotamia as historia sacra, at least in its incipient stages. The biblical concept of historia sacra implies these same two ideas: 'connective justice' and divine intervention. Divine intervention is not sufficient to define the biblical concept of history; it clearly defines the event, but not the concatenation of events into a coherent storyline. The concept of history needs connectives, such as causality: event $\mathrm{A}$ led to a state $\mathrm{B}$, which through divine intervention or any other event $C$ was transformed into a state $D$, and so forth. This connective principle is provided by 'connective justice'. In other words, connective justice functions like causality, defining an ensuing event not just as an 'effect' but in terms of reward and punishment. ${ }^{22}$

In Mesopotamia the gods appear as the agents of justice. This has much to do with divination, which played an absolutely central role in Babylonia. Everything depends on the correct interpretion of the signs expressing the will of the gods. A sign points to a future event and presupposes a finality between the will of the gods and the vicissitudes of history. In Egypt the will of the gods is absorbed in the task of maintaining the world; in Mesopotamia the divine will is sufficiently free to extend its range into human affairs. As a result, history forms a realm of religious meaning and experience, and becomes a matter of discursive communication and representation. ${ }^{23}$ Even in Egypt, this model grows more and more influential and leads to considerable changes, especially in the historiographical genres: the private autobiography and the royal inscriptions. ${ }^{24}$ The traditional theology of maintenance is complemented by a theology of will that imbues the realm of kheperut ('all that happens') with meaning.

In Mesopotamia the gods intervene in history because they are explicitly invited to do so. The theologization of history results from certain institutions of international law. Unlike Egypt, which knew a central government right from the start, Mesopotamia went through a long period of polycentrism, with city-states related to each other by treaties and conflicts. In this situation Mesopotamia formed concepts and institutions not only of national but also of international law. The political institutions of the city-state were able to maintain justice within the state, but for the maintenance of law and order among the various states the gods were made responsible. They were called upon to watch over the strict observance of the treaties between states and to punish any transgressions. Treaties had to be sealed by a solemn oath sworn by both parties submitting themselves to divine supervision. ${ }^{25}$ In the same way as the legal institutions of the state maintain justice inside the state, so the will and the 'wrath' of the gods maintain justice between states.

This tradition of international law leads in the Hittite Empire to the formation of two different contexts for the representation of the past. One 
is the same as in Mesopotamia: the context of justice and guilt. When a catastrophe occurs, it will be traced back to the intervention of an offended deity. The typical offence is the violation of a treaty. Divine wrath can only be reconciled by confession and repentance. This leads to discourses of historical reconstruction. The most elaborate examples are the confessory prayers of King Mursilis, who after twenty years of pestilence tried to reconcile the gods by publicly confessing a sin committed more than twenty years before by his father, who broke a treaty with the Egyptians by attacking the Syrian town of Amqa, which then belonged to Egypt. These prayers, together with the annals of his father, Shuppiluliuma, telling the same story, figure among the most elaborate pieces of cuneiform historiography. ${ }^{26}$

The other context of reconstructing the past is the Hittite custom of introducing state treaties with a long recapitulation of the common history of both parties forming the alliance. The alliance is built upon the foundation of a past of mutual friendship and support, giving reason to believe in the stability of the contract and the loyalty of the partners. ${ }^{27}$

A third genre of representing the past is the royal apology. This genre too flourishes in Hittite historiography, which has transmitted to us the most impressive and elaborate examples, especially the historical accounts of usurpers such as Telepinus or Hattusilis III. These usurpers want to justify their illegitimate ascension to the throne by pointing out the obvious blessing the gods bestow on their reign, or pointing out the injustice of their predecessors, the ensuing misfortunes, and the turn for the better brought about by their own rule. ${ }^{28}$

All three of these traditional genres of cuneiform historiography come to their fullest fruition only in the Bible, where they develop into large-scale compositions comprising one or even several entire books. The first form, which we may call confessory historiography, generates in the Bible the 'Deuteronomic' tradition of history-writing, in which every reign is judged according to the principle of the king's obedience to the law and which, with few exceptions, is a long story of disobedience, disloyalty, apostasy, injustice, and idolatry - in short, a story of an accumulation of guilt leading finally to the catastrophe of the destruction of Jerusalem and the Babylonian exile. The second form, which may be called covenantal history, lies behind the books of Exodus and Deuteronomy, where the law-that is, the treaty proper-is introduced by the history of how God intervened for the redemption of his chosen people. The book of Deuteronomy contains not only the historical introduction and the body of stipulations, but even the curses that traditionally form the close of a treaty. ${ }^{29}$ The third form, the royal apology, is represented in the Bible by the elaborate accounts dedicated to the reigns of 
kings Saul, David, and Solomon, and especially to David, whose dynastic legitimacy was more than dubious. ${ }^{30}$

Biblical historiography is the apex of Mesopotamian and Hittite traditions of history-writing. The development that leads in the Bible to its ultimate perfection can be identified as the sacralization of history. The idea of forming an alliance with God Himself, and with one God only instead of appointing several gods as supervisors of political alliances, draws this one chosen God much closer into the ups and downs of his chosen people than had been the case in Mesopotamia and its neighboring civilizations. There, history was just a field of possible favourable or punishing interventions by the gods; now it turns into one coherent connection of events, stretching from creation until the end of the world, known as historia sacra in the Judaeo-Christian tradition. Within the frame of historia sacra, the concatenation of events is structured not only by reward and punishment but also, and above all, by promise and providence. Historia sacra is not only a representation of the past, but also a project and a program. This aspect seems to be lacking in Mesopotamia.

The Mesopotamian and Hittite conceptions of history emerge, as we have seen, in the context of moral and legal thinking, and remain to be closely connected to the notions of law, guilt, verdict, and punishment, right through the entire biblical tradition up to its secularized version in Hegel's philosophy of history, as most clearly expressed in his formula 'Die Weltgeschichte ist das Weltgericht', which is a quote from Schiller's poem Resignation. No concept of history could claim more actuality for our present concern with the representation of the past than this most ancient and original concept of history. Especially in Germany, guilt has confirmed itself as the strongest and most productive generator of historical discourse. The juridical frame of accountgiving, of accepting responsibility not only for one's own deeds but also for a past stretching into several generations of predecessors, especially in the international context of alliances to be formed and maintained, remains or becomes again the most prominent context for the the reconstruction and communication of the past.

Where in this tableau, however, is the place of human history, historia profana, so to speak, history as a purely human affair without divine impact? It is this question that leads to the recognition of Herodotus as the 'father of history'. Herodotus seems to have been the first writer to narrate the past for its own sake, to interpret events as consequences not of divine intervention but of human decisions and actions. He seems also to have been the first to ask for causality and not for justice in the course of history. In this respect, Christian Meier, for instance, is right to recognize only the work of Herodotus as historiography, and to exclude all that has emerged in the ancient Near East long before Herodotus in forms of narrative representations of the past. ${ }^{31}$ Meier not only 
denies these Mesopotamian and biblical forms of representing the past any claim to be recognized as historiography, he even takes them to be the contrary of historiography, that is, to belong to myth. For Meier, Herodotus' epoch-making achievement consists in the destruction of the very constructions that, in the ancient Near East, had made possible the articulation and representation of time past. Only the emancipation from sense-making assumptions of normative truth ('there cannot be what must not be') and connective justice (morally bad actions lead to disastrous results for the actor) opens the way for the contingency of history, its 'Eigensinn'. Seen from the vantage-point of this position, the oriental and biblical forms of historiography appear as the opposite of history, as the quintessential manifestations of what had to be overcome in order to break through towards history proper. ${ }^{32}$

The soundness of Meier's arguments cannot be denied. If we consider the Greek concept of history, both historia divina and historia sacra appear as myth. Fishbane's distinction makes it possible to solve this problem. There seem to be two different kinds of myth: one based on historia divina and related to mythical time, the absolute past 'in illo tempore'; and the other based on historia sacra and related to historical time. These myths are made of the stuff of history: they are not about the birth and death, the actions and sufferings of gods and demi-gods, but of human beings. However, they are not just narrative representations of the past as a series of events, but foundational stories that define the identity, the central values, and the common ideals of a group. Reserving the term 'myth' for narratives concerning historia divina would mean denying narratives such as the stories of the Exodus from Egypt the status of myth. Fishbane is certainly right to include the stories of the Exodus, Sinai, the wilderness, and conquest, or the stories about the patriarchs, Abraham, Isaac, Jacob, and Joseph, in his concept of myth. These are without any doubt foundational stories determining the memory and identity of Israel as a religious and ethnic community, taking place not 'in illo tempore' but in historical time (however fictional this placement may be).

However, may we perhaps go further and generalize the concept of historia sacra so far as to include all myths that are not historia divina taking place in illo tempore', but that are related to historical time? May we go so far as to allow other people, religions, cultures, and societies a historia sacra of their own, or is this concept by definition restricted to the Judaeo-Christian context? To be sure, the concept of historia sacra has semantic elements that defy any extension beyond biblical monotheism, Jewish or Christian. One such element is, above all, the concept of paganism, which is implied in its opposite term, historia profana. Historia profana is the history of the 'peoples', the 'nations' (goyim, gentium), as opposed to the history of the one chosen people. The concept of historia sacra rests, therefore, on what I have called the 
'Mosaic distinction'. ${ }^{33}$ We have to weaken the concept of historia sacra by this distinction between true religion and paganism in order to be able to understand the foundational myths of other peoples as their historiae sacrae. They are then to be defined as representations of their specific normative past based on: ( $a$ ) a concept of connective justice or morality; $(b)$ a notion of sacrality, be it the will of God or an emphatic notion of community, nation, and empire; and $(c)$ an idea of promise, project, or program involving goals to achieve, ideals to realize, and values to enforce. I am wondering whether, in an age of globalization, this weak or extended notion of historia sacra is not gaining momentum. There are goals that 'we', as humanity and inhabitants of this endangered planet, must achieve, and there are things we must never forget in order to achieve these goals.

\section{NOTES}

1. Michael Fishbane, Biblical Myth and Rabbinic Mythmaking (Oxford: Oxford University Press, 2003).

2. Yehezkel Kaufmann, 'The Bible and Mythological Polytheism', JBL 70 (1951), 182, quoted after Fishbane, Biblical Myth, 6, n. 22.

3. For a similar rejection of the mythlessness of the Hebrew Bible, see Ignác Goldziher, Der Mythos bei den Hebräern und seine geschichtliche Entwicklung: Untersuchungen zur Mythologie und Religionswissenschaft (Leipzig, 1876; repr. Leipzig: Zentralantiquariat der DDR, 1987).

4. Fishbane, Biblical Myth, 11.

5. Ibid. 134; similarly in "The Holy One Sits and Roars": Mythopoesis and the Midrashic Imagination', Journal of Jewish Thought and Philosophy, 1 (1991), 16; repr. in The Exegetical Imagination: On Jewish Thought and Theology (Cambridge, Mass.: Harvard University Press, 1998), 35.

6. See my book Thomas Mann und Ägypten: Mythos und Monotheismus in den Josephromanen (Munich: C. H. Beck, 2006).

7. This applies, of course, only to the general and conventional concept of monotheism that Michael Fishbane so brilliantly deconstructs. On closer inspection, there are many aspects and motifs of a 'divine world' even in the Bible, i.e. partners other than human of God's actions and communications.

8. Eliade used this term in many of his books; see especially Le Mythe de l'éternel retour (Paris: Gallimard, 1949), passim.

9. For the concept of anti-history, see my 'Zeitkonstruktion, Vergangenheitsbezug und Geschichtsbewußtsein im alten Ägypten', in Jan Assmann and Klaus E. Müller (eds.), Der Ursprung der Geschichte: archaische Kulturen, das Alte Ägypten und das frühe Griechenland (Stuttgart: Klett-Cotta, 2005), 112-214. 
10. Johan Huizinga, 'A Definition of the Concept of History', in Raymond Klibansky and H. J. Paton (eds.), Philosophy and History: Essays Presented to Ernst Cassirer (New York: Harper \& Row, 1963), 9.

11. Donald B. Redford, Pharaonic King-Lists, Annals and Day-Books: A Contribution to the Study of the Egyptian Sense of History (Mississauga: Benben, 1986).

12. Claude Lévi-Strauss, La Pensée sauvage (Paris: Plon 1962), 309.

13. Instruction for Merikare, P 136-7; see Joachim Friedrich Quack, Studien zur Lehre für Merikare (Wiesbaden: O. Harrassowitz 1992), $78 \mathrm{f}$.

14. See Claus Wilcke, 'Die Sumerische Königsliste und erzählte Vergangenheit', in Jürgen von Ungern-Sternberg and Hansjörg Reinau, (eds.), Vergangenheit in mündlicher Überlieferung, (Stuttgart: Teubner, 1988), 113-40.

15. In a similar way, the demythologized biblical history, starting with Abraham, is prefixed by an account of the creation and a complete list of heroes, notable as such by their fantastic life-spans, and the carefully comprehensive enumeration of biblical genealogies reflects the system of the oriental king-lists.

16. Jean-Jacques Glassner, Chroniques mésopotamiennes (Paris: Les Belles Lettres, 1993).

17. Adam Falkenstein, 'Fluch über Akkade', ZA 57 (1965), 43 ff.

18. Albert Kirk Grayson, Assyrian and Babylonian Chronicles (Locust Valley, NY: Augustin, 1975), no. 19.

19. Wilcke, 'Die Sumerische Königsliste', 113-140.

20. Bertil Albrektson, History and the Gods: An Essay on the Idea of Historical Events as Divine Manifestations in the Ancient Near East and in Israel, Coniectanea Biblica, Old Testament Series 1 (Lund: Gleerup, 1967).

21. For the concept of iustitia connectiva, see my book Ma'at: Gerechtigkeit und Unsterblichkeit im alten Ägypten (Munich: C. H. Beck, 1990), 60-9.

22. Cf. Hans Kelsen, Vergeltung und Kausalität: eine soziologische Untersuchung (The Hague: Stockum \& Zoon, 1941; repr. Vienna: Boehlau, 1982); cf. id., Society and Nature: A Sociological Inquiry (Chicago: University of Chicago Press, 1943).

23. Jean Bottéro, 'Symptomes, signes, écritures', in J. P. Vernant et al. (eds.), Divination et rationalité (Paris: Éditions du Seuil, 1974), 70-198.

24. See my Ma'at, 252-72; id., 'State and Religion in the New Kingdom', in William Kelly Simpson (ed.), Religion and Philosophy in Ancient Egypt (New Haven: Yale University Press, 1989), 55-88.

25. On ancient treaties, see Luciano Canfora, Mario Liverani, and Carlo Zaccagnini (eds.), I trattati nel mondo antico: forma, ideologia, funzione (Rome: L'Erma di Bretschneider, 1990).

26. Cf. Albrecht Goetze, Mursilis II. König der Hethiter: Die Annalen (Leipzig: Hinrichs, 1933; repr. Darmstadt: Wissenschaftliche Buchgesellschaft 1967); id., 'Die Pestgebete des Mursilis', Kleinasiatische Forschungen, 1 (1930), 61-251; Hans Gustav Güterbock, 'The Deeds of Suppiluliuma as Told by His Son Mursili II', JCS 10 (1956), 41-50, 59-68, 75-85, 90-8, 107-30; Harry A. Hoffner, Jr., 'Propaganda and Political Justification in Hittite Historiography', in Hans Goedicke and J. J. M. Roberts (eds.), Unity and Diversity: Essays 
in the History, Literature, and Religion of the Ancient Near East (Baltimore: Johns Hopkins University Press, 1975), 49-64; id., 'Histories and Historians of the Near East: The Hittites', Orientalia, 49 (1980), 283-332; Hubert Cancik, Grundzüge der hethitischen und alttestamentlichen Geschichtsschreibung, Abhandlungen des deutschen Palästinavereins (Wiesbaden: Harrassowitz, 1976).

27. Klaus Baltzer, Das Bundesformular, 2d edn. (Neukirchen: Neukirchener Verlag, 1964).

28. Albrecht Goetze, Hattusilis. Der Bericht über seine Thronbesteigung, nebst den Paralleltexten (Darmstadt: Wiss. Buchges, 1967).

29. Delbert R. Hillers, Treaty-Curses and the Old Testament Prophets, Biblica et Orientalia 16 (Rome: Pontifical Biblical Institute, 1964). For the parallels between the biblical and ancient oriental ideas of covenant, especially Assyrian treaties, see esp. Moshe Weinfeld, Deuteronomy and the Deuteronomic School (Oxford: Oxford University Press, 1972), 116 ff.; Dennis J. McCarthy, Treaty and Covenant, new edn., Analecta Biblica 21 (Rome: Biblical Institute, 1978); Moshe Weinfeld, 'The Common Heritage of the Covenantal Traditions in the Ancient World', in Canfora, Liverani, and Zaccagnini (eds.), I trattati nel mondo antico, 175-91.

30. See Hayim Tadmor, 'Autobiographical Apology in the Royal Assyrian Literature', in Hayim Tadmor and Moshe Weinfeld (eds.), History, Historiography and Interpretation: Studies in Biblical and Cuneiform Literatures (Jerusalem: Magnes Press, 1986), 36-57.

31. Christian Meier, 'Historical Answers to Historical Questions: The Origins of History in Ancient Greece', Herodotus and the Invention of History, special issue of Arethusa, 20: 1-2 (1987), 41-57.

32. Christian Meier, Athen (Berlin: Siedler, 1993), $589 \mathrm{ff}$.

33. By this term, I understand the distinction between true and false in the realm of religion, between true and false gods and beliefs. See my book Moses the Egyptian: The Memory of Egypt in Western Monotheism (Cambridge, Mass. Harvard University Press, 1997). 